Penicillium and Streptomyces filtrates had a stability time of 4-6 days.

This work was performed under contract with the U.S. Army Chemical Corps, Fort Detrick, Frederick, Maryland.

U.S. Public Health Service,

ROBERT L. Bunch

EDWIN F. BARTH, JUN.

Robert A. Taft Sanitary Engineering Center, Cincinnati 26, Ohio.

${ }^{2}$ Ouchterlony, O., Acta Path. et Microbiol. Scand., 32, 231 (1953). 2 Kauffmann, F., "The Differentiation of Escherichia and Klebsiella 'Types" 'Thomas, Springfield, Illinois, 1951).

${ }^{3}$ Ewing, W. H., Tatum, H. W., Davis, B. R., and Reavis, R. W., municable Disease Center, Atlanta, 1956).

\section{Progesterone in the Blood of the Laying Hen}

Fraps et al. ${ }^{1}$, using the bioassay method of Hooker and Forbes ${ }^{2}$, reported progestational activity in the peripheral blood of the hen. Layne et al. ${ }^{3}$, using chromatographic procedures, failed to find progesterone in chicken blood although they did identify this substance in extracts of ovarian tissue. In preliminary studies in this laboratory ${ }^{4}$, chemical analysis failed to reveal progesterone in blood obtained by cardiac puncture, though the samples reacted positively to the Hooker-Forbes test.

Since progesterone is metabolized by the liver ${ }^{5}$, and perhaps by other body tissues as well, a method was devised to minimize such loss. Samples were obtained from White Leghorn hens, six to fourteen months old, between 8.00 a.m. and 4.00 p.m. on the day following oviposition of the initial egg of a sequence. The adrenal glands wero cauterized in birds under nembutal anæsthesia, and clamps were placed on the dorsal aorta posterior to the ovarian artery, on both common iliac veins just posterior to the caudal vena cava and on the vena cava anterior to the ovarian veins. The vena cava was opened distal to the last-mentioned clamp, and blood was drawn by suction during the period of $15-25 \mathrm{~min}$. before heart action ceased; $20-35 \mathrm{ml}$. was obtained from each bird. These samples thus contained a large proportion of blood from the ovary prior to contact with the liver or any capillary bed.

Five samples, each containing $300 \mathrm{ml}$, were extracted with ethyl acetate by the method of $\mathrm{Bush}^{6}$; fat was removed by adding 70 per cent methanol, chilling overnight to $-10^{\circ} \mathrm{C}$., and centrifuging at that temperature. The concentrated extracts were run on Whatman No. 2 chromatography paper, using $n$-heptane/methanol/water in the ratio of $5: 4: 1$ at $38^{\circ}$ C., after the method of Bush $^{6}$. Authentic progesterone in this system had an $R_{F}$ value of $0 \cdot 73-0 \cdot 76$.

All extracts yielded fluorescent spots, each with the same $R_{F}$ value as the authentic standard on the same paper. Two of these spots, treated with sodium hydroxide, developed the primrose-yellow fluorescence characteristic of an alpha-beta unsaturated ketone in ring $A$, and one spot, treated with 2,4-dintrophenylhydrazine ${ }^{7}$, developed a visible light-yellow colour indistinguishable from that of a similarly treated authentic progesterone. The quantities of progesterone in these three spots, estimated by comparison with progesterone standards, were all more than 10 and less than $20 \mathrm{ugm}$.; thus, these extracts contained an average of $5 \mu \mathrm{gm}$. progesterone per $100 \mathrm{ml}$. blood.
Two spots were eluted with ethyl acetate, and the residue taken up in sulphuric acid for absorption determination ${ }^{8}$ at $300 \mathrm{~m} \mu$. The amounts determined by this method were, respectively, 4 and $5 \mathrm{ugm}$. per $100 \mathrm{ml}$

Chemical identification of progesterone in these samples was doubtless made possible in large part by circumventing its loss in the peripheral tissues. Improved extraction techniques must also have been important, because earlier samples up to $150 \mathrm{ml}$. in amount, which were obtained in the same way but were less completely defatted, uniformly failed to yield detectable amounts of progesterone; yet these samples were positive to the Hooker-Forbes test. Application of these techniques to studies of diurnal variation of progesterone-levels in hen's blood will be reported elsewhere.

We are indebted to the National Research Council, Committee on Problems of Sex, for a grant in aid of research (S-11-57) that made this work possible.

I. M. LYTLE

University of California,

F. W. LORENZ

\section{Davis. Oet. 15}

${ }^{1}$ Fraps, R. M., Hooker, C. W., and Forbes, T. R., Science, 108, 86 (1948).

${ }^{2}$ Hooker, C. W., and Forbes, T. R., Endocrinol., 41, 158 (1947).

${ }^{3}$ Layne, D. S., Commons, R. H., Haw, W., and Fraps, R. M., Proc. Soc. Exp. Biol. Med., 94, 528 (1957).
Sil.,

' Lytle, I. M., master's degree thesis, University of California. Davis (1956).

${ }^{5}$ Wiswell, J. G., and Samuels, L. T., J. Biol. Chem., 201, 155 (1953).

${ }^{8}$ Bush, I. E., Biochem. J., 50, 370 (1952).

Kochakian, C. D., and Stitworthy, G. J., J. Biol. Chem., 192, 607 (1952).

${ }^{8}$ Linford, J. H., Canad. J. Biochem. Physiol., 35, 299 (1957).

\section{Effect of Triiodothyronine on Radiosensitivity}

REDUCTION in metabolic rate has been shown to reduce radiosensitivity, but the effect of an elevated metabolic rate has not been well established. Similarly, anoxia induced by various means reduces radiosensitivity. In recent years, the reverse of this phenomenon has been applied in the attempt to increase the radiation response. This is based on the assumption that the radiosensitivity of tissue is related to the degree of oxygen tension in a given tissue at the time of irradiation. Data on the protective action of myxœedema are not extensive; the hyperthyroid state has been shown to hasten mortality in mice given acute lethal doses of totalbody irradiation ${ }^{2,3}$.

Thyroid hormone is known to produce an increase in the metabolic rate, increased oxygen consumption, flow of blood, and growth potential, demonstrated by enhanced mitotic activity. It was therefore postulated that such stimulation might also lead to an increase in the radiosensitivity of selected local tissues, both normal and neoplastic.

L-Triodothyronine sodium, the potent fraction of the thyroid hormone that acts rapidly at the cellular level ${ }^{4}$, was selected to induce the hyperthyroid state. (L-Triiodothyronine sodium was kindly supplied as 'Cytomel'-sodium by J. Clipson of Smith, Kline and French Research Laboratories.)

Two abnormal tissues were used: (1) a solid, non-metastasizing, non-systemic, myeloid chloroleukæmia rat tumour ; (2) a mouse neuroblastoma of similar biological action. The latter tumour is so radio-resistant that it causes the mouse to succumb to 